\title{
Analytical Study of Influence of pH and weight Loss on Steel Corrosion Embedded in Reinforced Concrete: A Review Paper
}

\author{
Ashutosh S. Trivedi ${ }^{1 *}$, Dr Sudhir Singh Bhadauria ${ }^{2}$ and Ravi Singh Sengar ${ }^{3}$ \\ 1,2,3 Department of Civil Engineering, RGTU Bhopal, M.P., India \\ $1^{*}$ ashnriju@rediffmail.com, ${ }^{2}$ ssbrgpv@gmail.com, ${ }^{3}$ ravisingh.sengar@yahoo.com
}

\begin{abstract}
The present review paper discusses an aspect of influence of $p H$ and weight loss of steel embedded in reinforced cement concrete. Fe415 steel is the widely used steel in construction industry because of its low carbon content and good mechanical properties. To make an analytical study, the Linear Polarization Resistance (LPR) measurement technique has been used for measurement of $\mathrm{pH}$ and weight loss in 0.5M NaOH Solution The $\mathrm{pH}$ has been varied from 7-10 by a difference of 0.5. An equation which relates the $\mathrm{pH}$ and corrosion rates has also been dictated in the present paper. A wide literature review has also been conducted in the present paper. Temperature and the electrode voltage relationship have been shown in the text according to the Nernst equation.
\end{abstract}

Keywords: pH, Temperature, Corrosion, Weight Loss

\section{Introduction}

Reinforced concrete has the potential to be very durable and capable of withstanding the variety of adverse environmental condition. The effect of temperature on steel corrosion in concrete can be quite complex and it is due to many parameters. In reinforced concrete, steel provides the tensile properties which are needed in structural concrete. Concrete normally provides high degree of protection to the reinforcing steel against corrosion by the virtue of high alkalinity $(\mathrm{pH}>13.5)$ of the pore solution. The weight and Linear polarisation methods of evaluating the corrosion rate were used with $0.5 \mathrm{M}$ concentration of $\mathrm{NaOH}$ solution for experimental work. Corrosion rate increases with increment in temperature for almost all chemical process. Arrhenius equation relates these two parameters as shown in eq.1. From this equation, it can be concluded that with increases in temperature corrosion rates increases exponentially. While with variation in temperature $\mathrm{pH}$ value also varies.

$$
i_{c}=A e^{-E / R T}
$$

Where

- $\mathrm{i}_{\mathrm{c}}$ is the corrosion rate

- A is the Arrhenius pre-exponential factor

- $E$ is the activation energy

- $\mathrm{R}$ is the universal gas constant

- $\mathrm{T}$ is the absolute temperature

Equation 2 represents the relation between $\mathrm{pH}$ and corrosion current. The value of constant ' $\mathrm{A}$ ' obtained by different researchers has been shown in Table 1.

$$
\log \mathrm{i}_{\mathrm{c}}=-A \times \mathrm{pH}+B
$$

\footnotetext{
* Corresponding Author
} 
Table 1. Value of Constant 'A' by Different Researcher

\begin{tabular}{|l|l|l|}
\hline Researcher & A & Mechanism Considered \\
\hline Mukhtar et al [1] & 1.0 & Anodic reaction does not depend on $\mathrm{pH}$ \\
\hline Bockris et al [2] & 0.5 & Anodic reaction inversely proportional to $\mathrm{H}^{+}$concentration \\
\hline Raphel [3] & 1.2 & Hydrogen ion concentration with acidic solution \\
\hline
\end{tabular}

\subsection{Electrode Slope Dependence on Temperature}

Nernst Equation which relates the temperature with voltage of an electrode for half-cell and full-cell cases. Eq. 4 and 5 shows the Nernst equation for two cases half-cell and fullcell respectively.

$$
\begin{array}{r}
E_{\text {half-cell }}=E_{\text {half-cell }}^{o}+\frac{R T}{\mathrm{z} f} \ln \frac{a_{o x}}{a_{o y}} \\
E_{\text {cell }}=E_{\text {cell }}^{o}-\frac{R T}{\mathrm{z} f} \ln Q_{r}
\end{array}
$$

Where

- $E_{\text {half-cell }}$ is the potential for half-cell at the interest temperature

- $E_{\text {half-cell }}^{o}$ is the standard potential for half-cell

- $E_{c e l l}$ is the potential for full cell at the interest temperature

- $E_{\text {cell }}^{o}$ is the standard potential for half-cell

- $T$ is the absolute temperature

- $a_{o x}$ is an-oxidizing agent

- $a_{o y}$ is the reducing agent

- $R$ is the universal gas constant $\left(6.023 \times 10^{23}\right)$

- $Z$ is the no. moles in reaction

- $f$ is the faraday's constant

- $Q_{r}$ is the reaction quotient

\section{Literature Review}

Ghaz et al., [5] studied the high-temperature effect on the corrosion of steel through simulate polarization resistance test and model development by using Laplace equation to study corrosion rate temperature and concrete resistivity. Escudero and Macias [6] studied the effect of fluoride on corrosion of reinforcing steel in alkaline solutions by means of electrochemical techniques in saturated solution of $\mathrm{Ca}(\mathrm{OH})_{2}$ and $\mathrm{pH}$ of $\mathrm{NaOH}$ solution with additions of $\mathrm{NaF}$ and came to conclusion that the corrosion behaviour of reinforced steel in concrete made with cement manufactured employing fluorides cannot be very different from that in concrete made with traditional cement. Apostolopoulos and Papadakis [7] studied the consequences of steel corrosion on the ductility properties of reinforcement bar for the initiation mechanism leading to steel de-passivation i.e., carbonation and chloride penetration and they form loss in steel mass increases.

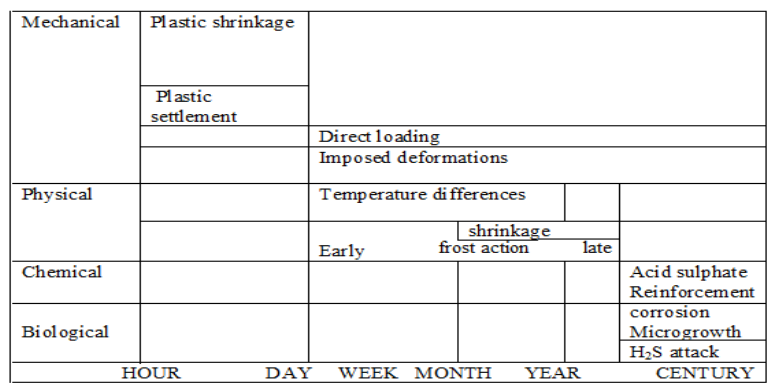

Figure 1. Concrete Deterioration Mechanisms and Possible Time of Appearance of Cracking or Damage 
Song and Saraswathy [8] studied the corrosion monitoring of reinforced concrete structures by electrochemical and non destructive techniques and their application to buildings bridges and other structures by different methods in their review paper and reported that the electrical resistivity of concrete as an effective parameter to evaluate the risk of reinforcing steel corrosion and their details are shown in Table 2.

Table 2. Corrosion Risk from Resistivity

\begin{tabular}{|l|l|}
\hline Resistivity (Ohm.cm) & Corrosion risk \\
\hline Greater than 20,000 & Negligible \\
\hline $10000-20000$ & Low \\
\hline $5000-10000$ & High \\
\hline Less than 5000 & Very high \\
\hline
\end{tabular}

A number of electrochemical rebar corrosion measurement and techniques available are reviewed. Each technique is reviewed to possess with certain advantages and limitations and communicated finally in his paper that sensors are also used on structures exhibiting corrosion as a part of rehabilitation energy to assess the effectiveness of repairs. Arredondo et al., [9] studied the carbonation rate and reinforcing steel corrosion of concretes with recycled concrete aggregates and supplementary cementing materials. Concrete carbonation is one of the main causes of reinforcement electrochemical corrosion. The corrosion rate of steel embedded in concrete has been measured by the linear polarisation resistance technique. Due to the significant environmental impact that the concrete production causes, and as sustainability contribution for this industry; presently some improvements are being implemented in its durability and its components are been replaced for alternative recyclable materials and came to conclusion that to use $100 \%$ RCA increases in $20 \%$ the total porosity and decreases the compressive strength in $15 \%$ respect to reference mixture.

Suo, Stewart et al., [10] studied the corrosion cracking prediction updating of deteriorating RC structures using inspection information. It is well known that the corrosion-induced cracking of reinforced concrete $(\mathrm{RC})$ structures vary in time and space due to the inherent spatial variability of concrete cover, concrete strength, surface chloride concentration and other material, environmental and dimensional properties and came to conclusion that how to reduce the uncertainties when predicting future corrosion damage by utilizing visual inspection findings. The influence of different inspection findings and inspection intervals on the likelihood and extent of corrosion damage (cover cracking) is studied by numerical simulation using a spatial time-dependent reliability analysis.

Cleland et al., [11] studied the corrosion of patch reinforcement repair in concrete structures. They show how the repair material influences the resistance to corrosion of reinforcement by experimentally investigating the provide data on the performance of repair materials in preventing corrosion of both coated and uncoated reinforcing bars and concluded that epoxy mortar exhibit small shrinkage compared to the cementitious material and also concluded that high permeability was measured at the interface of the cementitious mortars and surrounding concrete but not at the interface between the epoxy or flowing concrete and surrounding concrete.

Xiang et al., [12] studied the corrosion behaviour of X70 steel in the $\mathrm{CO}_{2} / \mathrm{SO}_{2} / \mathrm{O}_{2} / \mathrm{H}_{2} \mathrm{O}$ environment affected by high temperature. 


\section{Table 3. Represents Researchers Work about Temperature Effect on} Corrosion Rate

\begin{tabular}{|c|c|c|c|}
\hline Author's & Material use & Environment & Temperature \\
\hline Shariff et al [22] & AISI 304 & $\mathrm{CO}_{2}$ & $700^{\circ} \mathrm{C}$ \\
\hline Fazal et al [23] & Mild steel & Palm Biodiesel & $\begin{array}{l}\text { Room temp., } 50 \\
\& 80^{\circ} \mathrm{C}\end{array}$ \\
\hline Anderson [14] & $\begin{array}{l}\text { AISI } 304 \text { and Alloy } \\
600\end{array}$ & Water- $\mathrm{O}_{2}$ & $25-288^{\circ} \mathrm{C}$ \\
\hline Truman [18] & AISI 304 & $\mathrm{NaCl}$ & $\begin{array}{c}20,40,60 \& \\
100^{\circ} \mathrm{C}\end{array}$ \\
\hline Xiang et al [12] & X70 steel & $\mathrm{CO}_{2} / \mathrm{SO}_{2} / \mathrm{O}_{2} / \mathrm{H}_{2} \mathrm{O}$ & $\begin{array}{c}25,50,75 \& \\
94^{\circ} \mathrm{C}\end{array}$ \\
\hline Mesa et al [24] & $\begin{array}{c}\text { AISI } 420 \& \text { High } \\
\text { nitrogen martensitic } \\
\text { steel }\end{array}$ & $\begin{array}{c}\text { Ocean water \& Quartz } \\
\text { particles }\end{array}$ & $0,25 \& 70 \mathrm{C}$ \\
\hline Xin et al [13] & $\begin{array}{c}\text { Aluminium } 3003 \\
\text { alloy }\end{array}$ & Ethylene glycol & $30-80 \mathrm{C}$ \\
\hline Ismail et al [17] & X70 & ATCC 7757 & $5,20,37 \& 60 \mathrm{C}$ \\
\hline Qi et al [20] & $\begin{array}{l}\text { Carbon steel } \\
\text { (A350LF2) }\end{array}$ & Hydrogen Sulphide & $\begin{array}{c}25,40,60 \& \\
90^{\circ} \mathrm{C} \\
\end{array}$ \\
\hline Kairi \& Kassim [15] & Mild steel & HCL & $30-55 \mathrm{C}$ \\
\hline $\begin{array}{c}\text { Escudero and } \\
\text { Macias [6] }\end{array}$ & $\begin{array}{c}\mathrm{Ca}(\mathrm{OH})_{2}, \mathrm{NaOH} \text { and } \\
\mathrm{NaF}\end{array}$ & $\mathrm{pH} 12-23$ & Nil \\
\hline Apostolopoulos [7] & $\begin{array}{c}\mathrm{Ca}(\mathrm{OH})_{2}+\mathrm{CSH} \text { and } \\
\mathrm{NaCL} \text { steel grade BSt } \\
420\end{array}$ & $\mathrm{pH}$ around $12.6-9$ & $35^{\circ} \mathrm{C}$ \\
\hline Cleland et al. [11] & Mild steel bar & Epoxy & $20^{\circ} \mathrm{C}$ \\
\hline $\begin{array}{c}\text { Qinghui Suo and } \\
\text { Mark G. Stewart } \\
{[10]}\end{array}$ & $\mathrm{NaCL}$ & $\begin{array}{l}\text { Monte carlo } \\
\text { simulation }\end{array}$ & Nil \\
\hline $\begin{array}{c}\text { Rea Arredondo S. P. } \\
\text { et al [9] }\end{array}$ & $\begin{array}{l}\text { Recycled concrete } \\
\text { aggregate }\end{array}$ & $\begin{array}{l}\mathrm{pH}=13 \text { for } \\
\text { thermodynamic } \\
\text { stability }\end{array}$ & $28^{0} \pm 1$ \\
\hline
\end{tabular}

Xin et al., [13] studied 3003 aluminium alloy corrosion in ethylene glycol-water solution affected by temperature. Andresen [14] studied the temperature effect on the growth of crack for 304 stainless steel and 600 alloys.

Kairi and Kassim [15] studied the corrosion inhibition of mild steel affect by high temperature in 1M HCL solution. Table 3 represents the work conducted by researchers around the globe to see the effect of temperature.

Clarelli et al., [16] developed a mathematical model for copper corrosion detection due to sulphur dioxide $\mathrm{SO}_{2}$. The partial differential model developed by them can describe the damage evolution. In their experiments, they considered a bronze sample which was open to sulphur dioxide pollution $\left(\mathrm{SO}_{2}\right)$. The mathematical equation for saturated vapour density (SVD) as a function of temperature developed by them has been shown in equation 6 . While the results obtained by them for the behaviour of corrosion has been shown in Figure 2.

$$
\operatorname{SVD}(T)=5.018+0.32321 T+0.0081847 T^{2}+0.00031243 T^{3}
$$




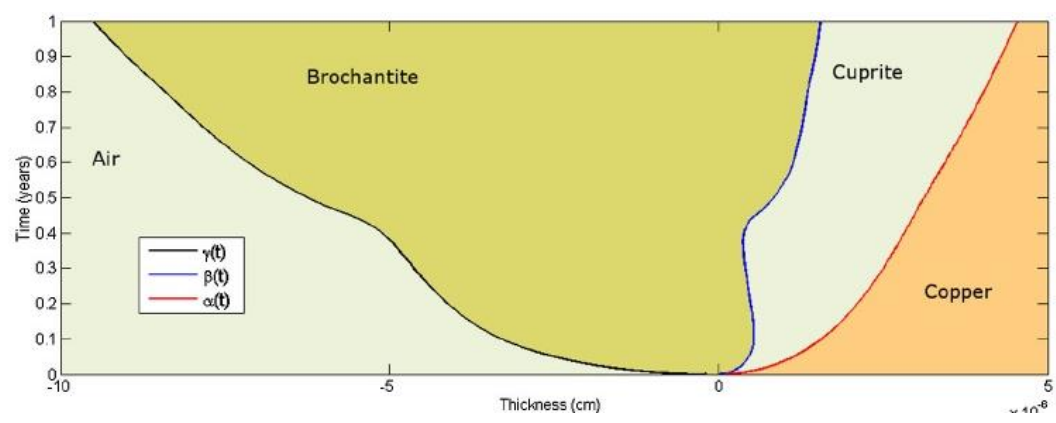

Figure 2. Behaviour of Corrosion with Environment

Ismail [17] studied the $\mathrm{pH}$ and temperature effect of SRB on steel corrosion. The variation of corrosion rates for carbon Steel with $\mathrm{pH}$ variation measured by them has been shown in Table 4.

Table 4. Variation of Corrosion Rate with pH [17]

\begin{tabular}{|l|l|l|l|l|l|l|l|l|l|}
\hline pH values & $\mathbf{5 . 5}$ & $\mathbf{6 . 0}$ & $\mathbf{6 . 5}$ & $\mathbf{7 . 0}$ & $\mathbf{7 . 5}$ & $\mathbf{8 . 0}$ & $\mathbf{8 . 5}$ & $\mathbf{9 . 0}$ & $\mathbf{9 . 5}$ \\
\hline CR $(\mathbf{m m} /$ year $)$ & 0.013 & 0.084 & 0.066 & 0.012 & 0.074 & 0.092 & 0.011 & 0.013 & 0.014 \\
\hline
\end{tabular}

Trumen [18] studied temperature, $\mathrm{pH}$ and chloride content effect with austenite stainless steel.

Chen and Brantley [19] studied the dissolution rate dependency on $\mathrm{pH}$ and temperature in acidic medium.

Table 5. Effect of Temperature and Flow Velocity on CR (Corrosion Rate)

\begin{tabular}{|c|c|c|c|c|c|}
\hline Author & $\begin{array}{c}\text { Flow } \\
\text { velocity } \\
(\mathrm{m} / \mathrm{s})\end{array}$ & $\begin{array}{c}\mathrm{CR}(\mathrm{Temp}): \\
\mathrm{mm} / \text { /year } \\
\left({ }^{\circ} \mathrm{C}\right)\end{array}$ & $\begin{array}{c}\mathrm{CR}(\text { Temp): } \\
\mathrm{mm} / \text { year }\left({ }^{\circ} \mathrm{C}\right)\end{array}$ & $\begin{array}{c}\mathrm{CR}(\text { Temp): } \\
\mathrm{mm} / \text { year }\left({ }^{\circ} \mathrm{C}\right)\end{array}$ & $\begin{array}{c}\mathrm{CR}(\text { Temp): } \\
\mathrm{mm} / \text { year }\left({ }^{\circ} \mathrm{C}\right)\end{array}$ \\
\hline Qi [20] & - & $0.56(25)$ & $0.905(40)$ & $0.28(60)$ & $0.224(90)$ \\
\hline Nesic et al [21] & 13 & $3.26(20)$ & $11.15(40)$ & $17.2(60)$ & $18.6(90)$ \\
\hline
\end{tabular}

Table 5 represents the effect of flow velocity and temperature on the corrosion rate. First row represents the work done by Qi [20] which has been conducted at the low flow rate while Nesic [21] has conducted the work on low flow velocity as well as for large velocity. It can be observed that the for low-velocity corrosion rate increases then decreases with increases in temperature while for large velocity it continuously increases up to $90^{\circ} \mathrm{C}$ Table 6 represents the effect of the $\mathrm{pH}$ values.

Table 6. Represents Researchers Work about pH Effect on Corrosion Rate

\begin{tabular}{|l|l|l|l|}
\hline Author's & Material use & Environment & Temperature \\
\hline Roy et al [25] & $\begin{array}{l}\text { Waste container } \\
\text { materials }\end{array}$ & Aqueous & $2,3,6,7,10$ \& 11 \\
\hline Tam \& Elefsiniotis [26] & Lead and Cu & $\begin{array}{l}\text { Alkaline and } \\
\text { orthophosphate }\end{array}$ & $7,7.5,8$ \& 9 \\
\hline Arjmand \& Adriaens [27] & Unalloyed Cu & NaCl & $3,7 \& 11$ \\
\hline Muslim et al [28] & $\mathrm{Al} \mathrm{\&} \mathrm{Cu}$ & Water & $4.7,7 \& 8.2$ \\
\hline
\end{tabular}

\subsection{Mild Steel Compositions}

It is also known as low carbon steel or plain carbon steel. It is the most extensively used because of its low cost. Its low carbon amount makes it suitable for low carbide 
precipitation during heat temperature treatment zone. It has upright mechanical properties in respective of the construction industries. Table 7 obtained from Indian standard code shows the general purpose composition of mild steel. Carbon percentage varies from 0.05 to $0.25 \%$. LPR measurement technique dictated below has been used in the present study to measure the corrosion rate.

Table 7. Mild Steel Compositions

\begin{tabular}{|l|l|l|l|l|l|}
\hline Material & Carbon & Manganese & Silicon & Phosphorous & Sulphur \\
\hline Amount (wt. \%) & $0.05-0.25$ & $0.7-0.9$ & $0.4 \% \max$ & $0.04 \max$ & $0.04 \max$ \\
\hline
\end{tabular}

\section{Experimental Methodology:}

Linear polarization method has been used to measure the corrosion rates of mild steel samples prepared. In this method one can use either three electrodes or two electrodes. Three electrodes method is used for measuring lower resistance and thus appropriate for solution with low thermal conductivity. In three electrode methods, one is working electrode, one is reference electrode and the last one is the conventional counter electrode. Figure 3 illustrates the three electrode method. A two electrodes measurement technique has been shown in Figure 4. In this technique no reference electrode is necessary. Where AUX=Auxiliary Electrode, WE=Working Electrode, REF=Reference Electrode.

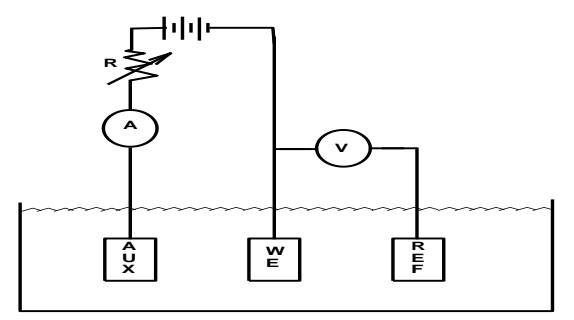

Figure 3. Three Electrode LPR Measurement Technique

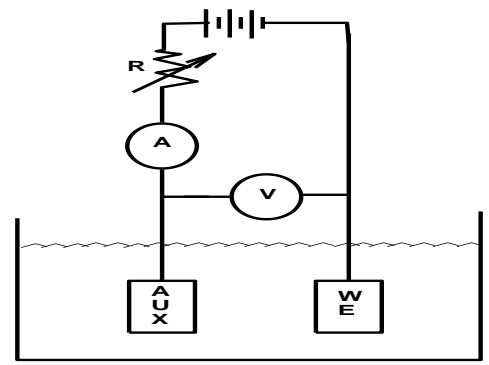

Figure 4. Two Electrode LPR Measurement Technique

\subsection{Weight Loss Measurement of Steel Embedded in Concrete}

To evaluate $\mathrm{pH}$ and weight loss in $\mathrm{Fe} 415$ steel bars, seventy two concrete mixes are prepared in $150 \times 150 \times 150 \mathrm{~mm}^{3}$ mould and a $12 \mathrm{~mm} \varnothing$ TMT steel bar of $200 \mathrm{~mm}$ length has been taken for experimental work which digitally weighed was embedded in concrete cube by keeping $20 \mathrm{~mm}$ cover on each side. The weight of each bar was found in grams up to three digits by using advance digitally weighing machine as shown in the figure 6 and their weights are recorded initially and after 28 days. The loss of weight of bar in gram is measured and tabulated below in Table 8 . The loss in weight is represented graphically in Figure 7. The specimens were de-moulded after 24 hours and kept in $\mathrm{NaOH}$ solution of $0.5 \mathrm{M}$ concentration to study the rate of corrosion as well as loss in weight of 
bar after initiation and 28 days respectively. After that, all samples were taken out and dried.

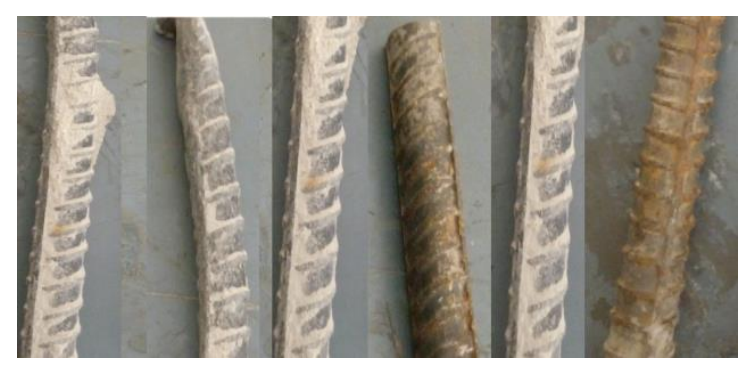

Figure 5. Shows Corrosion of Steel Bar Embedded in Reinforced Cement Concrete after 28 Days of Exposure

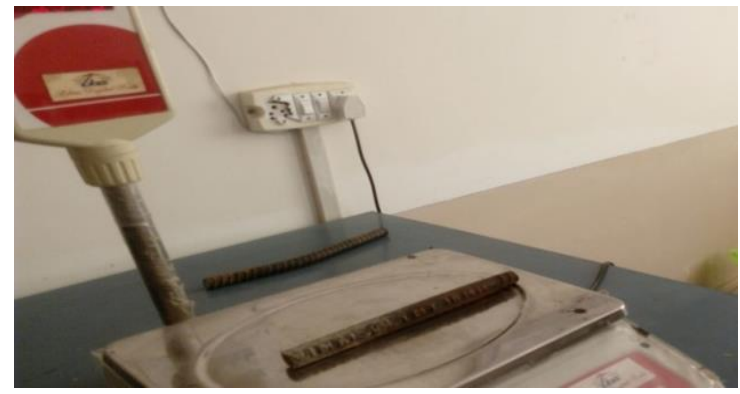

Figure 6. Weight of Steel Bar taken by Advance Digitally Weighing Machine

Table 8. Weight Loss of Steel Bars in Different Samples after 28 Days of Exposure

\begin{tabular}{|c|c|c|c|c|}
\hline Sample & $\begin{array}{l}\text { Original weight of } \\
\text { steel bars in gram }\end{array}$ & $\begin{array}{l}\text { weight of bars after the } \\
28 \text { days of exposure }\end{array}$ & $\begin{array}{l}\text { Loss of weight } \\
\text { (gram) }\end{array}$ & $\begin{array}{l}\text { Average Loss of } \\
\text { weight (gram) }\end{array}$ \\
\hline \multirow[t]{6}{*}{ Sample 1} & 179.54 & 179.51 & .03 & \multirow[t]{6}{*}{0.028} \\
\hline & 179.77 & 179.75 & .02 & \\
\hline & 179.65 & 179.61 & .04 & \\
\hline & 179.76 & 179.73 & .03 & \\
\hline & 179.60 & 179.57 & .03 & \\
\hline & 179.52 & 179.50 & .02 & \\
\hline \multirow[t]{6}{*}{ Sample 2} & 179.56 & 179.54 & 0.02 & \multirow[t]{6}{*}{0.018} \\
\hline & 179.59 & 179.57 & 0.02 & \\
\hline & 179.59 & 179.57 & 0.02 & \\
\hline & 179.86 & 179.85 & 0.01 & \\
\hline & 179.66 & 179.64 & 0.02 & \\
\hline & 179.84 & 179.82 & 0.02 & \\
\hline \multirow[t]{6}{*}{ Sample 3} & 179.52 & 179.50 & 0.02 & \multirow[t]{6}{*}{0.02} \\
\hline & 179.79 & 179.77 & 0.02 & \\
\hline & 179.78 & 179.76 & 0.02 & \\
\hline & 179.65 & 179.63 & 0.02 & \\
\hline & 179.59 & 179.56 & 0.03 & \\
\hline & 179.70 & 179.69 & 0.01 & \\
\hline \multirow[t]{4}{*}{ Sample 4} & 179.43 & 179.41 & 0.02 & \multirow[t]{4}{*}{0.022} \\
\hline & 179.76 & 179.74 & 0.02 & \\
\hline & 179.59 & 179.57 & 0.02 & \\
\hline & 179.90 & 179.88 & 0.02 & \\
\hline
\end{tabular}




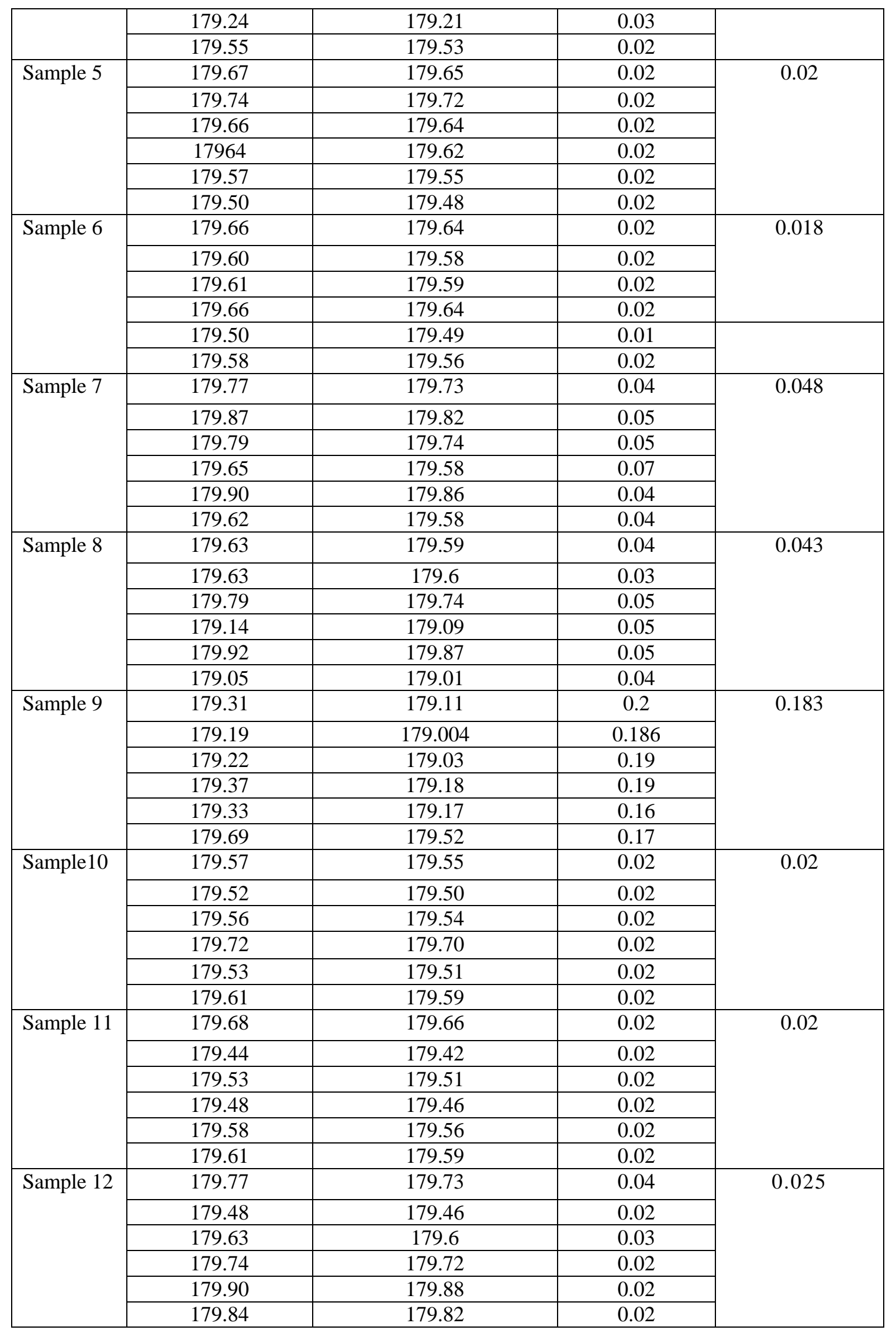




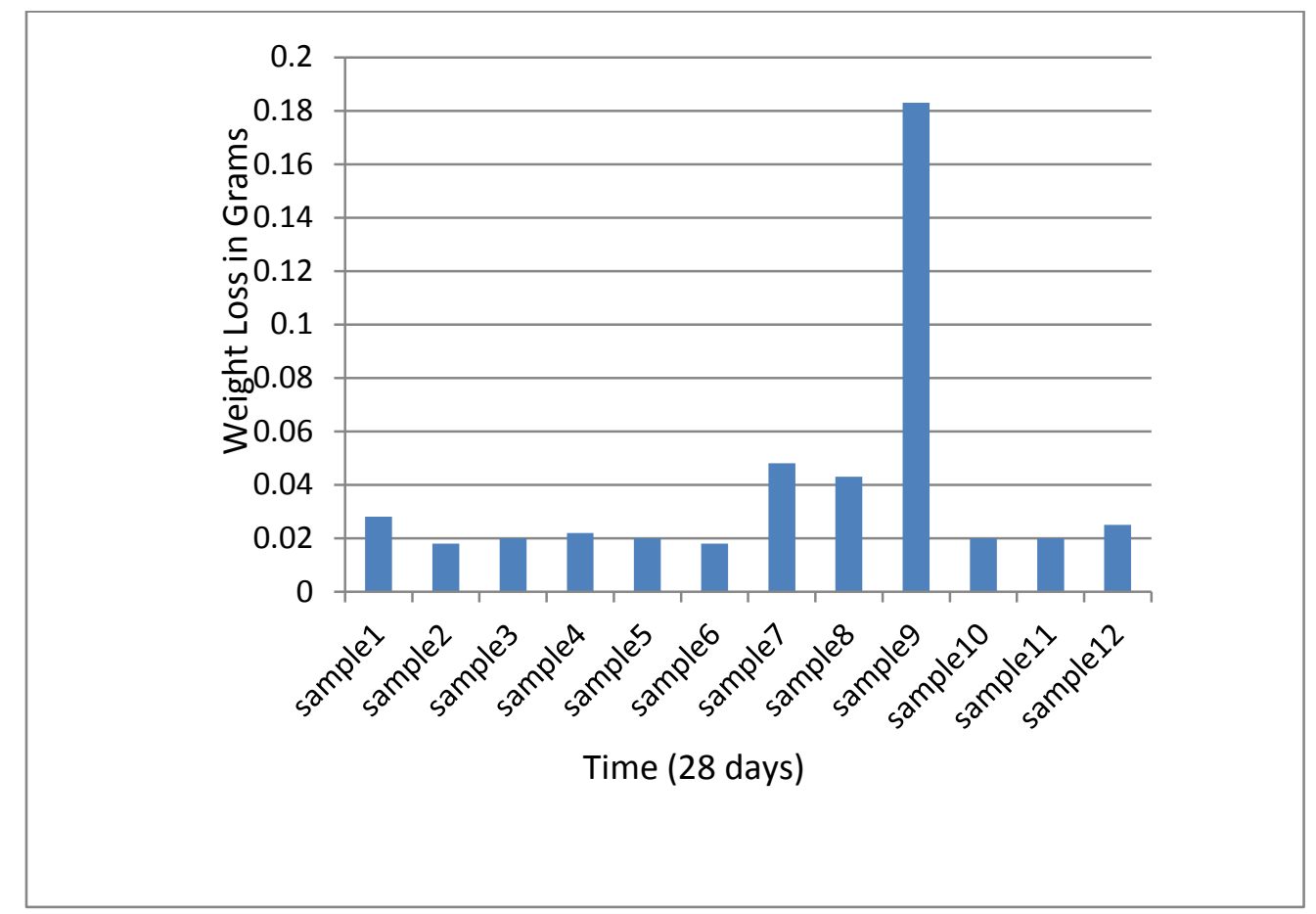

Figure 7. The Loss in Weight of Steel Bar with Time

\section{Result and Discussion}

A Sample of $3 \times 1 \times 0.15 \mathrm{~cm}$ has been cut from a sheet. A hole has been bored at the end of the sample for stress-free hanging. From Figure 8 it can be noticed that weight loss decreases with increment in $\mathrm{pH}$ value. While Figure 9 shows the relationship between the $\mathrm{pH}$ and the corrosion rate of the mild steel.

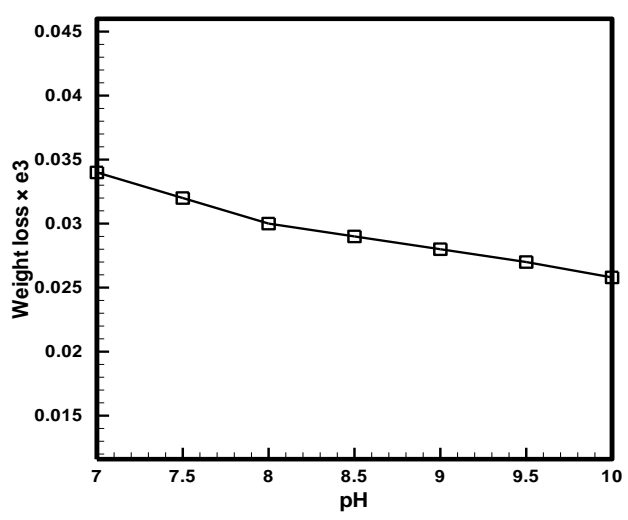

Figure 8. Effect of pH on Weight Loss 


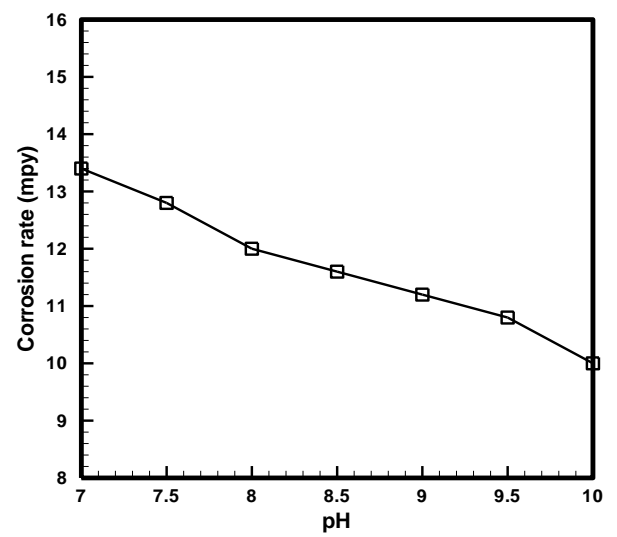

\section{Figure 9. Effect of pH on Corrosion Rate}

\section{Conclusion}

The corrosion of stainless steel (Fe415) in basic solution has been studied using weight loss by linear polarisation and electrochemical methods. The corrosion rate was found to increase with increasing temperature. It is necessary to take care of corrosion due to the $\mathrm{pH}$ related problem especially in the warm cities where the temperature is always around $35^{\circ} \mathrm{C}$ because rate of evaporation increases and water droplet stick to the surface of steel or concrete structure.

1. Corrosion rate increases with increment in the $\mathrm{pH}$ values.

2. Weight loss found to increases with $\mathrm{pH}$.

3. Arrhenius is the eq. which relates temperature and corrosion rate.

4. Material and solution properties also affect the rate of corrosion

\section{References}

[1] Mukhtar, "Estimation of Parameters of Arrhenius Equation for Ethyl Acetate Saponification Reaction", Research Journal of Chemical Sciences, vol. 5, no. 11, (2015), pp. 46-50.

[2] O'M. J. Bockris, "The Electrode Kinetics of the Deposition and Dissolution of Iron", Electro chemica Acta, vol. 4, no. 2-4, (1961), pp. 325-361.

[3] O. S. Raphel, "Corrosion Studies on Stainless Steel (FE6956) in Hydrochloric Acid Solution", Advances in Materials Physics and Chemistry, 4, (2014) pp. 153-163.

[4] C. D. Waard and D. E. Milliams, "Carbonic Acid Corrosion of Steel", Corrosion: Journal of science and engineering, vol. 31, no. 5, (1975), pp. 177-181.

[5] Ghaz (2009), "The Effect of Temperature on the Corrosion of Steel in Concrete. Part 1: Simulate Polarisation Resistance Tests and Model Development”, Corrosion Science, vol. 51, (1975), pp. 415425.

[6] L. M. Escudero and A. Macias, "The effect of Fluoride on Corrosion of Reinforcing Steel in Alkaline Solutions", Corrosion Science, vol. 36, no. 12, (1994), pp. 2169-2180.

[7] C. A. Apostolopoulos and V. G. Papadakis, "Consequences of Steel Corrosion on the Ductility Properties of Reinforcement Bar", Construction and Building Materials, vol. 22, (2008), pp. 2316-2324.

[8] H. Won Song and V. Saraswathy, "Corrosion Monitoring of Reinforced Concrete Structures", International Journal of Electrochemical Science, vol. 2, (2007), pp. 1602-1610.

[9] Arredondo, "Carbonation Rate and Reinforcing Steel Corrosion of Concretes with Recycled Concrete Aggregates and Supplementary", International Journal of Electrochemical Science, vol. 7, (2012), pp. 128.

[10] Q. Suo and M. G. Stewart, "Corrosion Cracking Prediction Updating of Deteriorating RC Structures using Inspection Information", Reliability Engineering and System Safety, vol. 94, (2009), pp. 1340134.

[11] Cleland, "Corrosion of Reinforcement in Concrete Repair", Construction and Building Materials, vol. 11, (1997), pp. 233-238. 
[12] Y. Xiang, "Effect of Temperature on Corrosion Behaviour of X70 Steel in High Pressure $\mathrm{CO} 2 / \mathrm{SO} 2 / \mathrm{O} 2 / \mathrm{H} 2 \mathrm{O}$ Environments, Corrosion Engineering, Science and Technology", vol. 48, no. 2, (2016), pp. 121-129.

[13] C. Xin, "Effect of Temperature on Corrosion Behaviour of 3003 Aluminium Alloy in Ethylene GlycolWater Solution", Chinese Journal of Aeronautics, Article in press, (2015).

[14] P. L. Andresen, "Effects of Temperature on Crack Growth Rate in Sensitized Type 304 Stainless Steel and Alloy 600", Corrosion Science, vol. 49, no. 9, (1993), pp. 714-725.

[15] N. I. Kairi and J. Kassim, "The Effect of Temperature on the Corrosion Inhibition of Mild Steel in $1 \mathrm{M}$ HCl Solution by Curcuma Longa Extract", International Journal of Electrochemical Science, vol. 8, (2013), pp. 7138-7155.

[16] F. Clarelli, "Mathematical model of Copper Corrosion", Applied Mathematical Modelling, vol. 38, no. 19-20, (2014), pp. 4804-4816.

[17] M. Ismail, "Effect of $\mathrm{pH}$ and Temperature on Corrosion of Steel subjected to Sulphate-ReducingBacteria", Journal of Environmental Science and Technology, vol. 7, no. 4, (2014), pp. 209-217.

[18] J. E. Truman, "The Influence of Chloride Content, $\mathrm{pH}$ and Temperature of Test Solution on the Occurrence of Stress Corrosion Cracking with Austenitic Stainless Steel”, Corrosion Science, vol. 17, no. 9, (1977), pp. 737-746.

[19] Y. Chen and S. L. Brantley, "Temperature- and pH-dependence of albite dissolution rate at acid pH", Chemical Geology, vol. 135, (1997), pp. 275-290.

[20] Y. Qi, "Effect of Temperature on the Corrosion Behaviour of Carbon Steel in Hydrogen Sulphide Environments", International Journal of Electrochemical Science, vol. 9, (2014), pp. 2101-2112.

[21] S. Nesic, "Probabilistic Modelling of CO2 Corrosion Laboratory Data Using Neural Networks", Corrosion Science, vol. 43, (2001), pp. 1373-1392.

[22] N. A. Shariff, "Effect of High Temperature Corrosion on Austenitic Stainless Steel Grade 304 in CO2 Gas at $700^{\circ} \mathrm{C} "$, Sains Malaysiana, vol. 43, no. 7, (2014), pp. 1069-1075.

[23] M. A. Fazal, "Effect of Temperature on the Corrosion Behaviour of Mild Steel upon Exposure to Palm Biodiesel, Proceeding of the International Conference on Advanced Science", Engineering and Information Technology, (2011), pp. 505-510.

[24] D. H. Mesa, "The Effect of Testing Temperature on Corrosion-Erosion Resistance of Martensitic Stainless Steels", Wear, vol. 255, (2003), pp. 139-145.

[25] A. K. Roy, "Effect of Chloride Concentration and $\mathrm{pH}$ on Pitting Corrosion of Waste Package Container Materials", 190th Meeting of The Electrochemical Society, San Antonio, (1996).

[26] Y. S. Tam and P. Elefsiniotis, "Corrosion Control in Water Supply Systems: Effect of pH, Alkalinity, and Orthophosphate on Lead and Copper Leaching from Brass Plumbing", Journal of Environmental Science and Health: Part A, vol. 44, (2009), pp. 1251-1260.

[27] F. Arjmand and A. Adriaens, "Influence of $\mathrm{pH}$ and Chloride Concentration on the Corrosion Behaviour of Unalloyed Copper in $\mathrm{NaCl}$ Solution: A Comparative Study between the Micro and Macro Scales", Materials, vol. 5, (2012), pp. 2439-2464.

[28] Z. R. Muslim, "The Effect of $\mathrm{pH}$ Level on Corrosion Rate of Aluminium and Copper", International Journal of Basic and Applied Science, vol. 2, no. 4, (2014), pp. 89-92. 
International Journal of Advanced Science and Technology Vol.91 (2016) 